\title{
Differential Induction of Chitinase and $\beta-1,3-$ Glucanase in Rice in Response to Inoculation with a Pathogen (Rhizoctonia solani) and a Non-Pathogen (Pestalotia palmarum)
}

\author{
S. D. DEBORAH, A. PALANISWAMI and R. VELAZHAHAN* \\ Department of Plant Pathology, Centre for Plant Protection Studies, \\ Tamil Nadu Agricultural University, Coimbatore-641 003, India
}

\begin{abstract}
Rice leaf sheaths were inoculated with $R$. solani (pathogen) and P. palmarum (non-pathogen) and were analyzed for the accumulation of pathogenesis-related (PR) proteins. Inoculation of rice plants with $R$. solani and P. palmarum resulted in a marked increase in activities of chitinase and $\beta-1,3$-glucanase. The levels of both enzymes were higher in incompatible interactions than in compatible interactions. Western blot analysis indicated that two proteins with molecular weights of 33 and $35 \mathrm{kDa}$ cross-reacting with barley chitinase antibody were induced in rice in response to inoculation with $R$. solani. The appearance of these chitinases was correlated with increase in enzyme activity.
\end{abstract}

Keywords: Compatible interaction, incompatible interaction, Pestalotia palmarum, Oryza sativa, PR-proteins, Rhizoctonia solani.

Plants, in general, possess several structural and biochemical defense mechanisms to overcome the infection by pathogens. Some of the chemical compounds are antifungal and are constitutive, existing in healthy plants. For example phenolics, phenolic glycosides, unsaturated lactones, saponins, cyanogenic glycosides, glucosinolates, 5-alkylated resorcinols and dienes (Osbourn, 1996). In addition to the preformed antimicrobial compounds, several defense mechanisms are induced in response to infection by potentially pathogenic microorganisms. These inducible defense responses include hypersensitive cell death (Levine et al., 1994), production of phytoalexins (Kuc and Rush, 1985), accumulation of Pathogenesis-Related (PR) proteins (Velazhahan et al., 1998, 2000), induction of oxidative burst (Baker and Orlandi, 1995), lignification (Ride, 1975) and cross-linking of wall glycoprotein (Bradley et al., 1992). The speed of expression of these defense genes determines the susceptible or resistant state of the host plant.

In recent years, much research has been focussed on PR-proteins (Datta and Muthukrishnan, 1999). The PR-proteins are a group of extracellular proteins that are induced by different phytopathogens such as fungi, bacteria and viruses, fungal elicitors and certain chemical inducers such as salicylic acid, polyacrylic acid and 2,6-dichloroisonicotinic acid (Bol et al., 1990; Uknes et al., 1992). These proteins have been extensively studied in tobacco and are identified in many monocotyledonous and dicotyledonous plants (Bol et al., 1990; Linthorst, 1991). Several studies suggested that the expression of PR-proteins correlated with the development of systemic acquired resistance 
(SAR) in plants (Ward et al., 1991; Uknes et al., 1992). Marked differences in the timing of activation of chitinase and glucanase genes in plants depending on compatibility or incompatibility of the interaction have been reported (Ward et al., 1991; Daugrois et al., 1990). We studied the changes in PR-proteins in rice in response to infection by Rhizoctonia solani, the rice sheath blight pathogen (a compatible interaction) and Pestalotia palmarum (nonpathogenic to rice: an incompatible interaction).

\section{Materials and Methods}

\section{Plant material}

The rice cultivar IR50 was used in all experiments. The seeds were obtained from Paddy Breeding Station, Tamil Nadu Agricultural University, Coimbatore. The plants were grown in $25 \mathrm{~cm}$ diameter earthern pots containing rice field soil in a greenhouse according to standard methods.

\section{Fungal culture and inoculation}

Rhizoctonia solani was isolated from sheath blight infected rice plants and maintained on Potato Dextrose Agar (PDA) medium. The fungus, Pestalotia palmarum was isolated from grey leaf spot infected coconut leaves and maintained on PDA medium. Individual tillers of 35 to 40 day old plants were inoculated with $R$. solani and P. palmarum by placing an agar block containing the mycelium on the leaf sheath and wrapping them with parafilm to maintain high humidity. At various times after inoculation, plant samples were collected and frozen in liquid nitrogen before protein extraction.

\section{Assay of chitinase}

Rice leaf sheaths $(1 \mathrm{~g})$ were homogenized in $5 \mathrm{ml}$ of $0.1 \mathrm{M}$ sodium citrate buffer (pH 5.0) using a chilled pestle and mortar. The homogenate was then centrifuged for 10 min at $10,000 \mathrm{~g}$ at $4{ }^{\circ} \mathrm{C}$ and the supernatant was used in the enzyme assay. Colloidal chitin was prepared from crab shell chitin (Sigma) according to Berger and Reynolds (1958). The commercial lyophilized snail gut enzyme (Helicase, obtained from Sepracor, France) was desalted as described by Boller and Mauch (1988). For the colorimetric assay of chitinase $10 \mu \mathrm{l}$ of $1 \mathrm{M}$ sodium acetate buffer $(\mathrm{pH} 4.0), 0.4 \mathrm{ml}$ of enzyme extract and $0.1 \mathrm{ml}$ colloidal chitin $(1 \mathrm{mg})$ were pipetted into a $1.5 \mathrm{ml}$ Eppendorf tube. After $2 \mathrm{~h}$ at $37^{\circ} \mathrm{C}$, the reaction was stopped by centrifugation at $1,000 \mathrm{~g}$ for $3 \mathrm{~min}$. An aliquot of the supernatant $(0.3 \mathrm{ml})$ was pipetted into a glass reagent tube containing $30 \mu \mathrm{l}$ of $1 \mathrm{M}$ potassium phosphate buffer (pH 7.1) and incubated with $20 \mu \mathrm{l}$ desalted snail gut enzyme for $1 \mathrm{~h}$. The resulting monomeric N-acetylglucosamine (GlcNAc) was determined according to Reissig et al. (1955) using internal standards of GlcNAc in the assay mixtures for calculations. Enzyme activity was expressed as nmol GlcNAc equivalents $\min ^{-1} \mathrm{~g}^{-1}$ fresh weight. 
Assay of $\beta$-1,3-glucanase

$\beta$-1,3-glucanase activity was assayed by the laminarin-dinitrosalicylate method (Pan et al., 1991). Rice leaf sheaths ( $1 \mathrm{~g}$ ) were extracted with $5 \mathrm{ml}$ of $0.05 \mathrm{M}$ sodium acetate buffer ( $\mathrm{pH}$ 5.0) by grinding at $4{ }^{\circ} \mathrm{C}$ using a pestle and mortar. The extract was then centrifuged at $10,000 \mathrm{~g}$ for $15 \mathrm{~min}$ at $4{ }^{\circ} \mathrm{C}$ and the supernatant was used in the enzyme assay. The reaction mixture consisted of $62.5 \mu \mathrm{l}$ of $4 \%$ laminarin and $62.5 \mu \mathrm{l}$ of enzyme extract. The reaction was carried out at $40{ }^{\circ} \mathrm{C}$ for $10 \mathrm{~min}$. The reaction was then stopped by adding $375 \mu \mathrm{l}$ of dinitrosalicylic reagent and heating for $5 \mathrm{~min}$ on a boiling water bath. The resulting coloured solution was diluted with $4.5 \mathrm{ml}$ of distilled water, vortexed and its absorbance at $500 \mathrm{~nm}$ was determined. Enzyme activity was expressed as nmol min ${ }^{-1} \mathrm{~g}^{-1}$ fresh weight.

\section{Western blot analysis}

Proteins were extracted from control and $R$. solani-inoculated leaf sheaths by grinding $1 \mathrm{~g}$ of tissues with $5 \mathrm{ml}$ of $0.1 \mathrm{M}$ phosphate buffer, $\mathrm{pH} 6.5$ containing $0.5 \mathrm{mM}$ phenylmethylsulphonyl fluoride as described by Velazhahan et al. (1998). Proteins (100 $\mu \mathrm{g}$ ) in aliquots of extracts were separated on 12\% SDS-PAGE (Laemmli, 1970) and electroblotted onto polyvinylene difluoride (PVDF) membrane (pore size $0.45 \mu \mathrm{m}$, BioRad) using BioRad semidry transfer cell in accordance with the manufacturer's instructions. Western blotting was carried out as described by Winston et al. (1987) with an antiserum raised against barley chitinase. The barley chitinase antiserum was a gift from Dr. S. Muthukrishnan, Kansas State University, USA. Apparent molecular mass of proteins was determined by comparison with molecular weight standards (Rainbow markers, Amersham Pharmacia, USA). Protein concentrations were determined by Bradford assay (Bradford, 1976).

\section{Results}

A significant increase in chitinase activity was observed in rice leaf sheaths after inoculation with $P$. palmarum. The maximum enzyme activity was recorded 2 days after inoculation subsequently the enzyme activity declined but remained significantly at higher levels when compared with control (Fig. 1). A 2-fold increase in chitinase activity occurred 2 days after inoculation with $P$. palmarum. $R$. solani-inoculated rice leaf sheaths showed sudden increase in chitinase activity 1 day after inoculation, subsequently the enzyme activity declined but the enzyme levels in infected leaf sheaths were significantly higher at all sampling stages when compared with control. To know whether the increase in chitinase activity in $R$. solani-inoculated rice leaf sheaths is due to de novo synthesis or due to post-translational modification of the pre-existing inactive enzyme, the crude proteins from $R$. solani-inoculated rice leaf sheaths at different time intervals were analyzed by Western blot analysis using barley chitinase antibody. A 35-kDa chitinase appeared $12 \mathrm{~h}$ after inoculation (Fig. 2). The induction of the chitinase was prominent 24-48 h after inoculation. Another chitinase with a molecular weight of $33 \mathrm{kDa}$ was detected 24-48h after inoculation. 


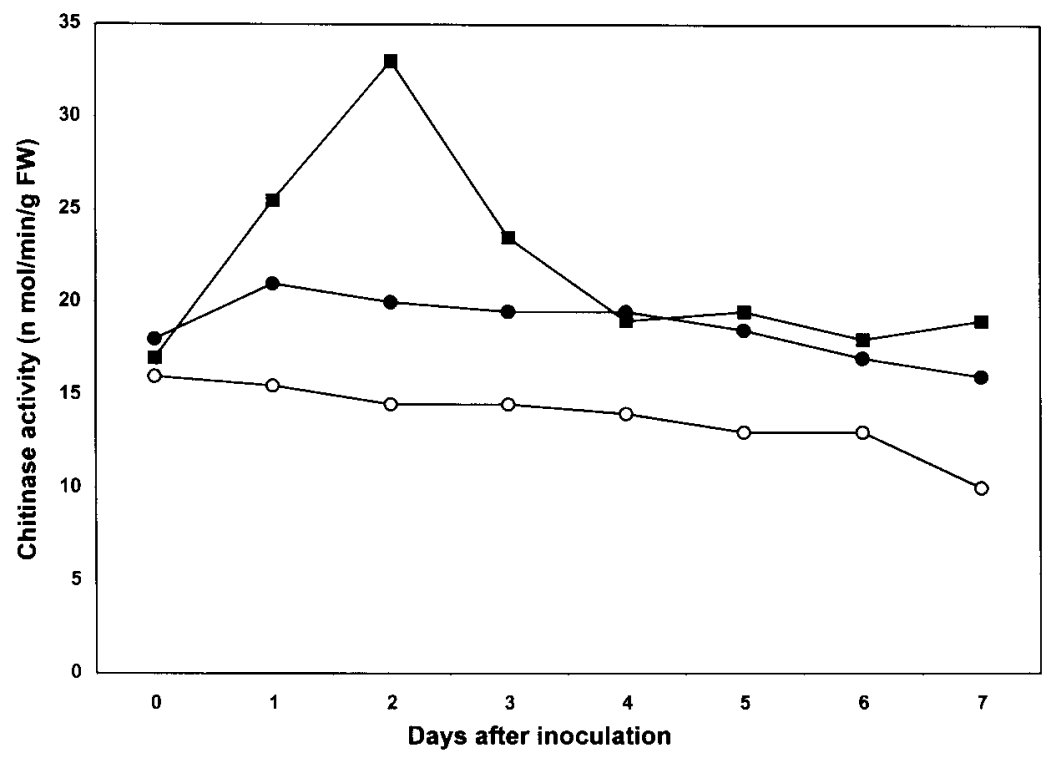

Fig. 1. Changes in chitinase activity in rice in response to inoculation with Rhizoctonia solani and Pestalotia palmarum. Chitinase activity in protein extracts of control $(-\mathrm{O}-)$,

$R$. solani-inoculated (- - ) and $P$. palmarum-inoculated $\left(-\mathbf{\square}_{-}\right.$) rice leaf sheaths was measured colorimetrically. Least significant difference to compare any two means at $\mathrm{P}=0.05$ is 3.39

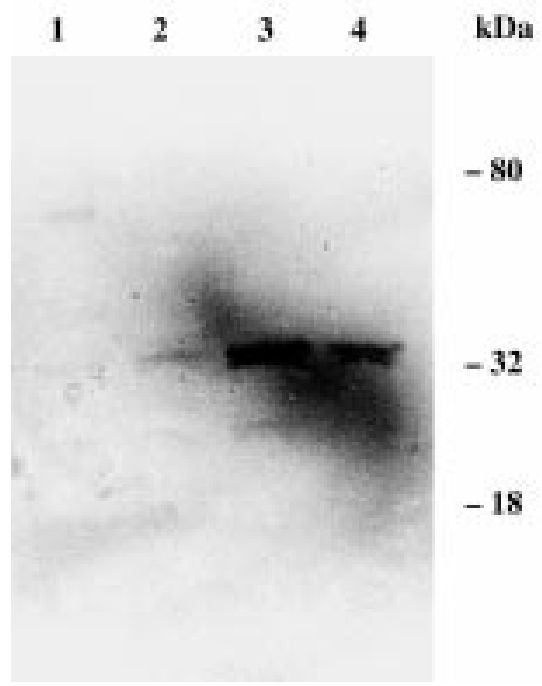

Fig. 2. Induction of chitinase in rice in response to inoculation with Rhizoctonia solani. Aliquots $(100 \mu \mathrm{g})$ of proteins extracted from control (lane 1) and $R$. solani-inoculated rice leaf sheath (lanes 2-4) were analyzed by Western blotting after SDS-PAGE, using a barley chitinase antiserum. Lane 2; $12 \mathrm{~h}$ after inoculation; Lane 3; $24 \mathrm{~h}$ after inoculation; Lane 4; $48 \mathrm{~h}$ after inoculation. Sizes of marker proteins are indicated on the right 


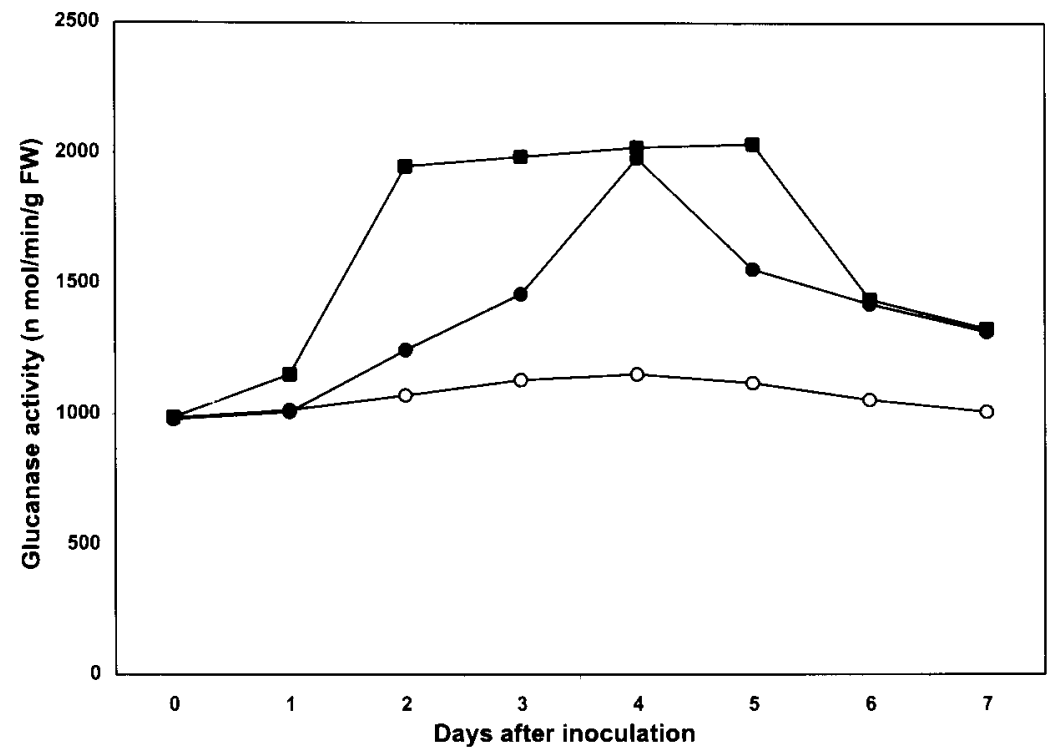

Fig. 3. Changes in $\beta-1,3$-glucanase activity in rice in response to inoculation with Rhizoctonia solani and Pestalotia palmarum.

Glucanase activity in protein extracts of control $(-\mathrm{O}-), R$. solani-inoculated $\left(-\mathbf{O}_{-}\right)$and $P$. palmarum-inoculated (- - ) rice leaf sheaths was measured colorimetrically. Least significant difference to compare any two means at $\mathrm{P}=0.05$ is 10.45

$\beta$-1,3-glucanase activity steadily increased in $R$. solani inoculated rice leaf sheaths from 2 days onwards and reached the maximum 4 days after inoculation (Fig. 3). The enzyme activity was significantly at higher levels at all sampling stages when compared with control. Rice leaf sheath responded to inoculation with P. palmarum with a rapid increase in glucanase activity from 1 day onwards and reached the maximum level at 5 days after inoculation. The levels of glucanase activity were higher in incompatible than in compatible interactions.

\section{Discussion}

Chitinases and $\beta$-1, 3-glucanases have been suggested to be involved in resistance of plants against fungal pathogens (Goy et al., 1992; Pan et al., 1991). Chitinases and $\beta$-1,3-glucanases have the potential to hydrolyze chitin and $\beta$-1,3-glucan respectively, which are major components of fungal cell walls, leading to direct inhibition of growth of several fungi (Schlumbaum et al., 1986; Leah et al., 1991). It has been demonstrated that both chitinases and $\beta$-1,3-glucanases from pea tissues acted synergistically in partial degradation of isolated fungal cell walls (Mauch et al., 1988). In addition chitinases and 
glucanases play an indirect role in stimulating plant defense by releasing oligosaccharides from the fungal cell walls by their enzymatic action which act as "elicitors" or inducers of several defense genes (Ryan, 1987; Keen and Yoshikawa, 1983). High constitutive levels of $\beta$-1,3-glucanase activity was found to be associated with leaf rust resistance in wheat (Anguelova et al., 1999). Similarly, higher levels of $\beta$-1,3-glucanase activity were recorded in resistant muskmelon plants than in susceptible plants (Ward et al., 1991).

Early increase in chitinase and glucanase activities has been correlated with resistance of plants against pathogens. In the resistant Brassica napus cultivar, the level of chitinase mRNA was three-folds higher than in the susceptible cultivar one day after inoculation (Rasmussen et al., 1992). In the present study, the time-courses of chitinase and glucanase activities in response to infection by $R$. solani and $P$. palmarum were examined. Inoculation of rice leaf sheaths with $R$. solani and $P$. palmarum resulted in a marked increase in activities of both chitinase and glucanase. The accumulation of both chitinase and glucanase was more in rice tissues infected with $P$. palmarum. The induction of glucanase in rice was much faster in incompatible interaction. Esnault et al. (1993) observed high-level accumulation of a $0.8 \mathrm{~kb}$ transcript encoding a PR-protein 6 to $30 \mathrm{~h}$ post infection in the incompatible interaction of alfalfa with Pseudomonas syringae pv. pisi. In contrast, the $0.8 \mathrm{~kb}$ transcript was undetectable in the compatible interaction with Xanthomonas campestris pv. alfalfae, even $30 \mathrm{~h}$ after infection. Similarly maximum accumulation of chalcone isomerase and isoflavone reductase transcripts was recorded $6 \mathrm{~h}$ post infection in incompatible interactions whereas in the compatible interaction, the induction of these transcripts was delayed until 25-30 h post infection. Similarly accumulation of chitinase mRNA was reported to start earlier in an incompatible interaction in bean - Colletotrichum lindemuthianum interaction (Bell et al., 1986; Hedrick et al., 1988). Daugrois et al. (1990) reported that the increase in $\beta$-1,3-glucanase and chitinase activities in bean were much faster in compatible interactions. In soybean roots infected by Phytophthora megasperma f. sp. glycinea, accumulation of PAL and chitinase mRNAs started earlier in incompatible than in compatible interaction (Habereder et al., 1989). However, Punja and Zhang (1993) reported higher levels of chitinase activity in infected susceptible plants than in resistant plants. They attributed this to stress levels induced by higher fungal biomass in susceptible plants. The results of the present study indicated that the accumulation of chitinase and $\beta$-1,3-glucanase was more pronounced in incompatible rice $-P$. palmarum interaction suggesting that these hydrolytic enzymes may play a role in resistance of rice to P. palmarum.

\section{Literature}

Anguelova, V. S., Westhuizen, A. J. and Van Derand Pretorius, Z. A. (1999): Intercellular proteins and $\beta-1,3$ glucanase activity associated with leaf rust resistance in wheat. Physiol. Plant. 106, 393-401.

Baker, C. J. and Orlandi, E. W. (1995): Active oxygen in plant-pathogen interactions. Annu. Rev. Phytopathol. 33, 299-321.

Bell, J. N., Ryder, T. B., Wingate, W. P. M., Bailey, J. A. and Lamb, C. J. (1986): Differential accumulation of plant defense gene transcripts in a compatible and an incompatible plant-pathogen interaction. Mol. Cell. Biol. 6, 1615-1623. 
Berger, L. R. and Reynolds, D. M. (1958): The chitinase system of a strain of Streptomyces griseus. Biochem. Biophys. Acta. 29, 522-534.

Bol, J. F., Linthorst, H. J. M. and Cornellissen, B. J. C. (1990): Plant pathogenesis-related proteins induced by virus infection. Annu. Rev. Phytopathol. 28, 113-138.

Boller, T. and Mauch, F. (1988): Colorimetric assay for chitinase. Meth. Enzymol. 161, 430-435.

Bradford, M. M. (1976): A rapid and sensitive method for the quantitation of microgram quantities of protein utilizing the principle of protein-dye binding. Ann. Biochem. 72, 248-254.

Bradley, D. J., Kjellbom, P. and Lamb, C. J. (1992): Elicitor and wound-induced oxidative cross-linking of a proline-rich plant cell wall protein; A novel, rapid defense response. Cell 70, 21-30.

Datta, S. K. and Muthukrishnan, S. (1999). Pathogenesis-related proteins in plants. CRC Press, Boca Raton, FL, USA.

Daugrois, J. H., Lafitte, C., Barthe, J. P. and Touze, A. (1990): Induction of $\beta$-1,3-glucanase and chitinase activity in compatible and incompatible interactions between Colletotrichum lindemuthianum and bean cultivars . J. Phytopathol. 130, 225-234.

Esnault, R., Buffard, D., Breda, C., Sallaud, C., Turk, E. J. and Kondorosi, A. (1993): Pathological and molecular characterizations of alfalfa interactions with compatible and incompatible bacteria, Xanthomonas campestris pv. alfalfae and Pseudomonas syringae pv. pisi. Mol. Plant-Microbe Interact. 6, 655-664.

Goy, A. P., Felix, G., Metraux J. P. and Meins, F. Jr. (1992): Resistance to disease in the hybrid Nicotiana glutinosa X Nicotiana debneyi is associated with high constitutive level of $\beta$-1,3-glucanase, chitinase, peroxidase and polyphenol-oxidase. Physiol. Mol. Plant Pathol. 41, 11-21.

Habereder, H., Schroeder, G. and Ebel, J. (1989): Rapid induction of phenylalanine ammonia-lyase and chalcone synthase mRNAs during fungus infection of soybean (Glycine max L.) roots or elicitor treatment of soybean cell cultures at the onset of phytoalexin synthesis. Planta 177, 58-65.

Hedrick, S. A., Bell, J. N., Boller, T. and Lamb, C. J. (1988): Chitinase cDNA cloning and mRNA induction by fungal elicitor, wounding, and infection. Plant Physiol. 86, 182-186.

Keen, N. T. and Yoshikawa, M. (1983): $\beta$-1,3-glucanase from soybean releases elicitor-active carbohydrates from fungus cell walls. Plant Physiol. 71, 460-465.

Kuc, J. and Rush, J. S. (1985): Phytoalexins. Arch. Biochem. Biophys. 236, 455-472.

Laemmli, U. K. (1970): Cleavage of structural proteins during the assembly of the head of bacteriophage T4. Nature 227, 680-685.

Leah, R., Tommerup, H., Svendsen, I. and Mundy, J. (1991): Biochemical and molecular characterization of three barley seed proteins with antifungal properties. J. Biol. Chem. 266, 1564-1573.

Levine, A., Tenhaken, R., Dixon, R. and Lamb, C. (1994): $\mathrm{H}_{2} \mathrm{O}_{2}$ from the oxidative burst orchestrates the plant hypersensitive disease response. Cell 79, 583-593.

Linthorst, H. J. M. (1991): Pathogenesis-related proteins of plants. Crit. Rev. Plant Sci. 10, 123-150.

Mauch, F., Mauch-Mani, B. and Boller, T. (1988): Antifungal hydrolases in pea tissue. II. Inhibition of fungal growth by combinations of chitinase and $\beta$-1,3-glucanase. Plant Physiol. 88, 936-942.

Osbourn, A. E. (1996): Preformed antimicrobial compounds and plant defense against fungal attack. Plant Cell $8,1821-1831$.

Pan, S. Q., Ye, X. S. and Kuc, J. (1991): Association of $\beta$-1,3-glucanase activity and isoform pattern with systemic resistance to blue mold in tobacco induced by stem injection with Peronospora tabacina or leaf inoculation with tobacco mosaic virus. Physiol. Mol. Plant Pathol. 39, 25-39.

Punja, Z. K. and Zhang, Y. E. (1993): Plant chitinases and their role in resistance to fungal diseases. J. Nematol. $25,526-540$.

Rasmussen, U., Bojsen, K. and Collinge, D. B. (1992): Cloning and characterization of a pathogen-induced chitinase in Brassica napus. Plant Mol. Biol. 20, 277-287.

Reissig, J. L., Strominger, J. L. and Leloir, L. F. (1955): A modified colorimetric method for the estimation of N-acetylamino sugars. J. Biol. Chem. 217, 959-966.

Ride, J. P. (1975): Lignification in wounded wheat leaves in response to fungi and its possible role in resistance. Physiol. Plant Pathol. 5, 125-134. 
Ryan, C. A. (1987): Oligosaccharide signalling in plants. Annu. Rev. Cell Biol. 3, 295-317.

Schlumbaum, A., Mauch, F., Vogeli, U. and Boller, T. (1986): Plant chitinases are potent inhibitors of fungal growth. Nature 324, 365-367.

Uknes, S. J., Mauch-Mani, B., Moyer, M., Potter, S., Williams, S., Dincher, S., Chandler, D., Slusarenko, A., Ward, E. and Ryals, J. (1992): Acquired resistance in Arabidopsis. Plant Cell 4, 645-656.

Velazhahan, R., Cole. K. C., Anuratha, C. S. and Muthukrishnan, S. (1998): Induction of thaumatin-like proteins (TLPs) in Rhizoctonia solani-infected rice and characterization of two new cDNA clones. Physiol. Plant. 102, 21-28.

Velazhahan, R., Samiyappan, R. and Vidhyasekaran, P. (2000): Purification of an elicitor-inducible antifungal chitinase from suspension-cultured rice cells. Phytoparasitica 28, 131-139.

Ward, E. R., Uknes, S. J., Williams, S. C., Dincher, S. S., Wiederhold, D. L., Alexander, D. C., Ahl-Goy, P., Metraux, J. P. and Ryals, J. A. (1991): Coordinate gene activity in response to agents that induce systemic acquired resistance. Plant Cell 3, 1085-1094.

Winston, S., Fuller, S. and Hurrel, J. (1987): Western blotting. In: Ausubel, F., Brent, R., Kingston, R., Moore, D., Smith, S. J. and Struhl, K. (eds): Current Protocols in Molecular Biology. John Wiley, New York, NY. pp. 10.8.1-10.8.6. 